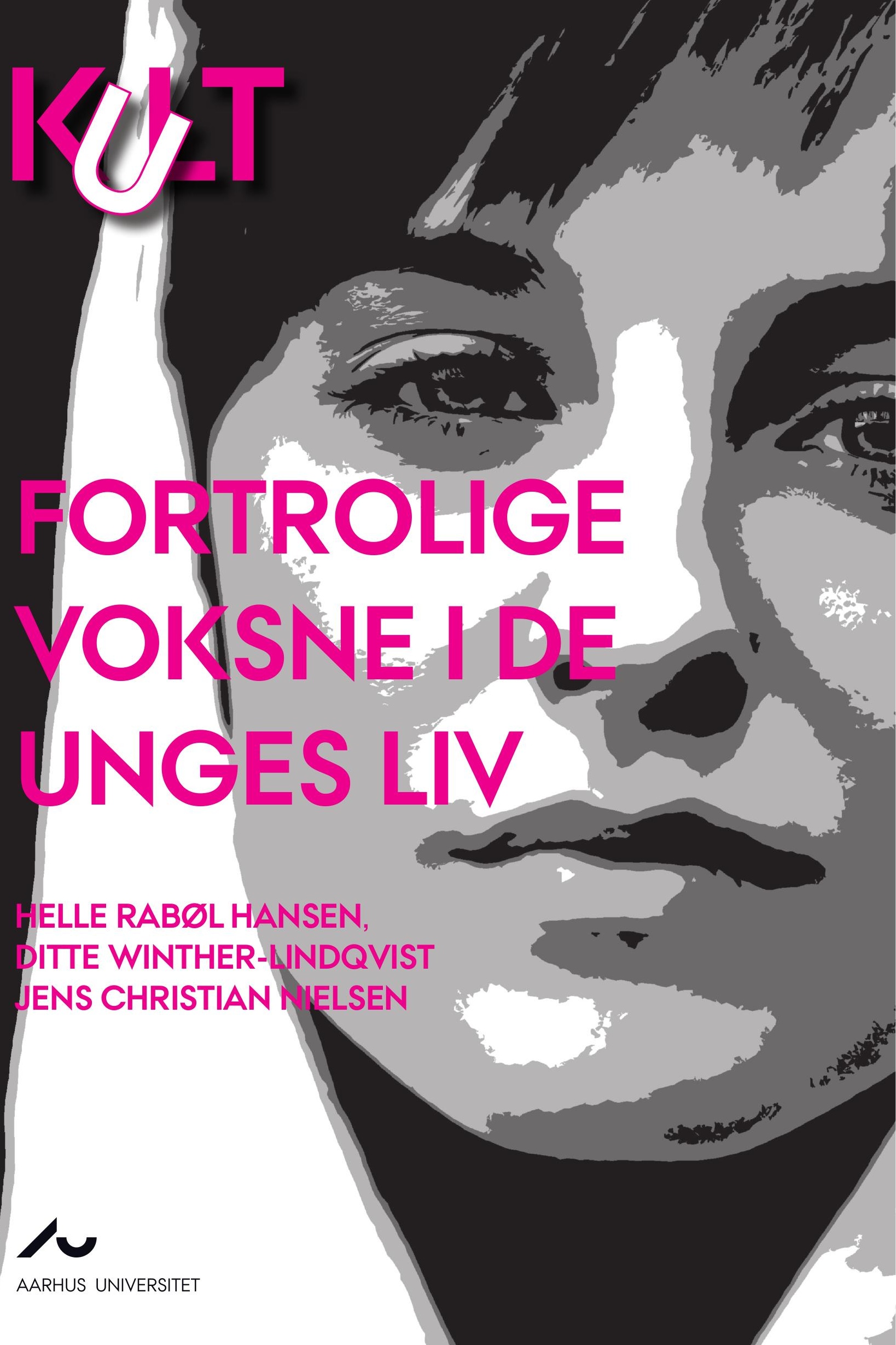



Helle Rabøl Hansen, Ditte Winther-Lindqvist og Jens Christian Nielsen

\section{Fortrolige voksne i de unges liv}


Titel:

Fortrolige voksne i de unges liv

Forfattere:

Helle Rabøl Hansen, Ditte Winther-Lindqvist og Jens Christian Nielsen

Udgivet af:

KULT - Konsortiet for forskning i Ungdomsliv, Læreprocesser og Transition

Institut for Uddannelse og Pædagogik (DPU), Aarhus Universitet, 2015

Rekvirent:

Gentofte Kommune

(C) 2015 , forfatterne

1. udgave

Kopiering tilladt med tydelig kildeangivelse

Omslag og grafisk tilrettelæggelse:

Knud Holt Nielsen

ISBN:

978-87-7684-762-3 


\section{Indhold}

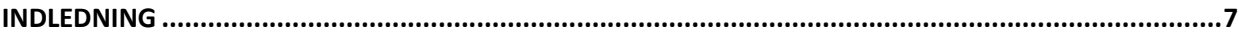

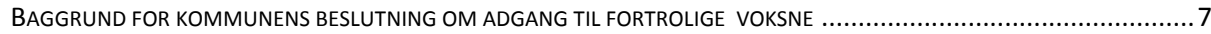

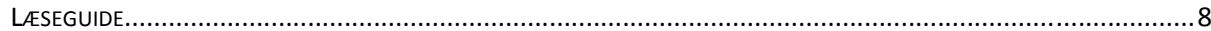

FORSTÅELSESRAMME OG BESKRIVELSER AF UDFORDRINGER I UNGDOMSLIVET ANNO 2015 I DANMARK .......................8

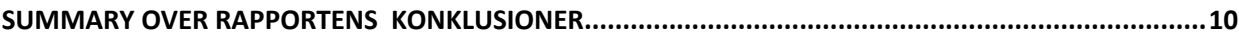

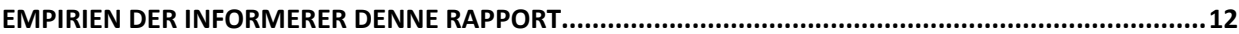

EN FORTROLIG VOKSEN - ANALYSE AF FORSKERNES EGEN EMPIRI: MED UNGE DER HAR EN SYG FORALLDER, TRIVSELSUNDERS $\varnothing$ GELSEN OG VESTEGNSUNDERS $\varnothing$ GELSEN, INKL. B ØRN MED MOBBEERFARINGER ................................13

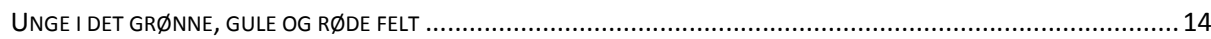

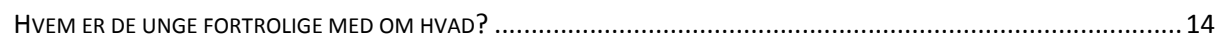

ANALYSE AF EMPIRI INDSAMLET I FORBINDELSE MED PROJEKT FORTROLIG VOKSEN........................18

ANALYSE AF 8. KLASSERNES ESSAYS OM FORTROLIGHED, TILLID OG VOKSNE .................................................... 18

ANALYSE AF GRUPPEINTERVIEW MED ELEVER FRA UNGDOMSSKOLEN ......................................................... 22

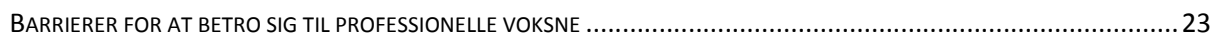

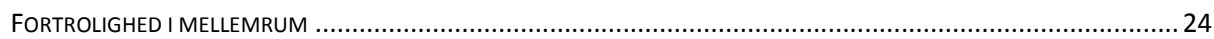

UKLARHED OM LAERERFAGLIGHEDEN I FORHOLD TIL AT VAERE EN FORTROLIGE VOKSNE FOR DE UNGE ..........................24

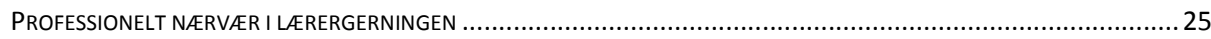

RUM FOR DIALOG MED UNGE OM UNGDOMSLIVETS UDFORDRINGER OG MISTRIVSEL .........................................26

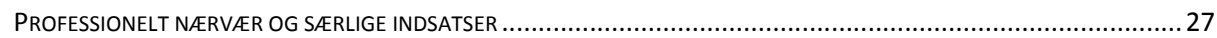

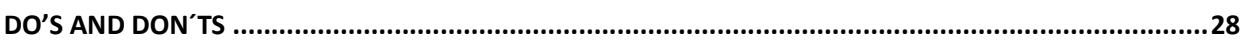

GODE RÅD TIL LÆERERE OG SKOLEPÆDAGOGER DER GERNE VIL VÆERE TILGÆENGELIGE SOM FORTROLIGE VOKSNE......................28

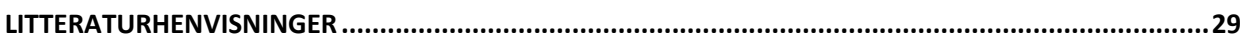





\section{Indledning}

Gentofte Kommune har i forbindelse med et kommunalt fremstød for den mentale sundhed, besluttet, at 90 pct. af kommunens unge i udskolingen fra 2015 skal have adgang til "En fortrolig voksen" i eller uden for skolen.

Ungdomsforskerne, adjunkt Helle Rabøl Hansen, lektor Ditte Winther Lindqvist og Lektor Jens Christian Nielsen fra Aarhus Universitet, Institut for Uddannelse og Pædagogik giver i denne rapport et empirisk-teoretisk bud på, hvordan begrebet "En fortrolig voksen" kan forstås.

De råd og analyser rapporten Fortrolige voksne $i$ de unges liv tilbyder, henvender sig til de professionelle voksne, som udskolingseleverne møder i institutionelle sammenhænge - og de voksne enkelte elever vil møde i myndighedssammenhænge. Vi koncentrerer os om de professionelle voksne i de unges liv, men når emnet angår fortrolighed, så fremhæver de unge i høj grad deres forældre og andre voksne fra den private sfære, som deres foretrukne fortrolige. Det er derfor en rammesætning for rapporten at de unge har forskellige forventninger og behov til deres forskellige voksne i livet, og vi har prøvet at indkredse hvilke forventninger de unge har til deres professionelle voksne, og hvilke emner og problemstillinger de netop knytter til fortroligheden med dem.

De fokus vi har anlagt om unges livsførelse i denne rapport, er primært rettet mod den del af unges tilværelse, der byder på negative udfordringer og hvor der kan være behov for at få adgang til en fortrolig voksen.

\section{Baggrund for kommunens beslutning om adgang til fortrolige voksne}

En kommunal undersøgelse peger på, at 66 pct. af de unge på 9. og 10. klassetrin ikke har fortrolige voksne på skolen, og at 16 pct. ikke har fortrolige voksne udenfor skolen (Gentofte Kommune 2012: Ryge- og rusmiddelvaner blandt unge, skoleåret 2011/2012). Vi forstår det sådan, at de fortrolige voksne som unge primært har adgang til udenfor skolen er deres forældre. Der er dog en restgruppe som af forskellige årsager ikke har denne form for forældrekontakt. På baggrund af resultaterne fra den kommunale undersøgelse kan man således forstå, at totredjedele af udskolingseleverne ikke har adgang til fortrolige voksne i deres daglige liv i skolen. Og hver sjette elev har ikke fortrolige voksne i deres fritids- og privatliv. 


\section{Lœseguide}

Rapporten er bygget op på den måde, at der efter de indledende bemærkninger præsentereres en tekst der generelt beskriver ungdomslivet i DK anno 2015. Herefter en kort summarytekst med rapportens hovedkonklusioner og anbefalinger. De efterfølgende afsnit i rapporten er gennemgange af de bagvedliggende analyser, beskrivelser af den nye empiri, og dermed det forskningsmæssige belæg for de konklusioner der drages.

\section{Forståelsesramme og beskrivelser af udfordringer i ungdomslivet anno 2015 i Danmark}

Det er en særlig udviklingsopgave at forlade barndommen og kaste sig ud i det nye og ukendte, som ungdomslivet indvarsler: Kropslige forandringer, de første seksuelle erfaringer, skoleskift, ændringer i venskabsrelationer, nye krav fra voksenverdenen osv. Identitetsspørgsmålet: Hvem er jeg? Hvem skal jeg blive? er spørgsmål, der ikke kun opleves frigørende, men også usikkerheds skabende. Det er de færreste, som kommer igennem ungdommen uden interessante udforskninger og uden udfordringer. Ungdomstiden består af en række spring, skift og overgange fx mellem skole og ungdomsuddannelse, hvor unge løbende må integrere sig blandt nye jævnaldrende og nye voksne i nye sammenhænge med nye spilleregler. Det er en af grundene til, at vi ofte forbinder ungdomsepoken med en stor åbenhed, mange muligheder, hastig udvikling, som ud over fest, ballade og øget frihed, samtidig kan medføre en betydelig sårbarhed (Winther-Lindqvist 2010). Et af de afgørende forhold for unges trivsel, er deres sociale integration på de mange arenaer, som deres hverdagsliv udfolder sig i: Familien, skolen, uddannelsen, arbejdet, fritiden osv. Det ser ud til at være afgørende for unges trivsel at opleve social integration i de fællesskaber med andre unge, som findes på disse arenaer. Samtidig ser det ud som om, at det også er vigtigt for unges selvbillede, at de føler sig accepteret af de voksne, der omgiver dem i hverdagslivet, hvad enten der er tale om forældre, lærere eller pædagoger (Hendry \& Kloep 2012). Dette behov for voksenaccept lever side om side med et behov der går i en anden retning nemlig behovet for at løsive sig fra de voksne. Den modsætning kan være svær at forstå for de voksne, der befinder sig i den unges liv. Her er det vigtigt, at de unge oplever, at de kan indfri de krav og forventninger, som stilles til dem. Det kan specifikt handle om at mestre skolegang og uddannelse, men det handler også om i videre forstand at kvalificere sig generelt til ungdoms- og sidenhen voksenlivet, lære at klare sig selv og kunne tage ansvar for sit eget liv (Mørch 2010, Illeris m.fl. 2009). 
Forældre fremskrives i vores empiri som centrale skikkelser i de unges liv. I medierne og i det pædagogiske felt fremhæves ofte de travle forældre, der har dårlig tid til deres børn i hverdagen, men ifølge flere undersøgelser oplever flertallet af de unge faktisk at deres forældre står til rådighed for dem (fx Kofod \& Nielsen 2005, Bach Ludvigsen \& Nielsen 2008). Stort set alle unge bor hjemme hos en eller begge forældre, og forholdet til dem og eventuelle søskende fylder en stor del i de unges liv. Men relationen til forældrene (og andre voksne autoritetsfigurer) i ungeårene rummer konfliktpotentiale, som kan få en helt særlig karakter, når udskolingseleven først står på tærsklen til ungdomslivet, og siden udlever det med øget løsrivelse, selvbestemmelse og ansvar til følge (Winther-Lindqvist 2010).

På baggrund af ovenstående beskrivelser kan vi pege på, at unge står midt i en tid i deres liv, hvor de samfundsmæssigt positioneres som en befolkningsgruppe i transition, og samtidigt lever de unge i en kulturel epoke med her-og-nu praksisser, der genkendes som ungdomskulturel livsstil. Unge står dermed i et krydsfelt mellem det bevægelige og processuelle at være i overgang til en uddannelses- eller job identitet og det mere værende - at leve i sin tid på den mest oplevelsesrige måde. Dertil kan man formentligt indlægge en specifik lokal dimension, da det ser ud til, at man blandt udskolingsunge i Gentofte Kommune i høj grad støder på problematikker, hvor der ligger en socioøkonomisk informeret forventning i miljøet om at være særlig succesfulde. I det empiriske baggrundsarbejde for denne rapport er vi eksempelvis stødt på fænomenet PiP, Piger i Pres, som vi har valgt som betegnelse for det forhold, at nogle piger oplever et betydeligt pres i retning af forventninger og krav om at være dygtig(st), smuk, sød og social ansvarlig. 


\section{Summary over rapportens konklusioner}

Unge der har mistet et nært familiemedlem, unge der er ramt af mobning, unge der er i talent- eller uddannelsespres eller unge, der er truet på deres grundlæggende livstrivsel svarer stort set på samme måde som når vi har spurgt 8. klasser i Gentofte Kommune om hvad de forstår ved en fortrolig voksen. Der går især tre hovedtemaer igen i besvarelserne:

1. En fortrolig voksen er en person man kan stole på (De holder tæt, og udstiller mig $i k k e)$.

2. En fortrolig voksen kan man dele følelser og tanker med (Fx mine hemmeligheder og personlige problemer).

3. En fortrolig voksen er en person, der udviser proaktiv interesse (De ser mig og bliver ved at se mig).

Fortrolighed forstås her som en relationel proces, hvor (indre) oplevede forhold kan udveksles, og hvor der samtidigt vises proaktiv (ydre) interesse for det fra den voksnes side.

Det ser ud til, at der navigeres på forskellige måder i ungdomskrydsfeltet. Nogle unge rammes på deres grundlæggende følelse af at høre til i samfundet. Andre ser ud til at gå mere ubekymret gennem ungdomstiden med få eller sjældne udfordringer. Uanset om man er mere eller mindre ramt af livsudfordringer ser det ud til, at unge i udskoling og under ungdomsuddannelse generelt kan have brug for voksenfortrolighed, når det handler om faglige udfordringer og social trivsel i de institutionelle sammenhænge de agerer i: skole, arbejde eller ungdomsuddannelse. Her er der tale om en mere almen adgang til fortrolighed hos de voksne, som udgør en (med)betingelse for de daglige samfundsmæssige aktiviteter. Derudover er der en mindre gruppe af elever, der er truet på deres grundlæggende trivsel og som kalder på en mere specifik form for fortrolighed med en voksen, de ikke er afhængige af i forbindelse med deres skole- og uddannelsesforløb.

Begrebet "En fortrolig voksen" bør derfor i højere grad forstås som "Fortrolige voksne" - i pluralis. Og i det plurale kan der peges på to hovedbehov: 
- For det første et behov for adgang til fortrolighed med lærere og pædagoger i forbindelse med skoleforhold såsom faglige og sociale udfordringer, forventningspres og skoleulyst.

- For det andet fortrolighed med en professionel omsorgsperson ( $\mathrm{fx}$ en mentor eller kontaktperson), når den unge er mere alvorligt udviklingstruet grundet svigt, sorg, angst, misbrug, selvskadende handlinger eller psykiske lidelser. Børn og unges kvalitative beretninger om fortrolighed taler for, at denne voksne omsorgsperson ikke kun er uafhængig af skolestruktur, men også er uafhængig i forhold til at træffe sociale afgørelser på den unges vegne som socialrådgivere, kuratorer o.a.

Vi skelner mellem to former for tilgængelighed til fortrolige som de unge har brug for. Den almindelige tilgængelighed fra opmærksomme voksne, som de fleste vil få glæde af og brug for i skolen - og en mere omfattende tilgængelighed fra en støtteperson, som enkelte unge har behov for i korte eller længere perioder af deres ungeliv. Begge former for tilbud om fortrolig faglighed forstås her som en psykosocial opgave og ikke en psykoterapeutisk opgave. Det betyder, at for såvel lærere/pædagoger i skolen som mentorer/kontaktpersoner udenfor skolen, fokuseres der på den unges personlige og sociale forhold som betingelser, der kan forbedres og udfordres. Der er ikke tale om terapeutiske tilbud - men for lærerene og pædagogernes vedkommende om at udvide de pædagogisk didaktiske erfaringer med øgede opmærksomheder på sammenhænge mellem fællesskaber, individer og sociale livsflader. Det vil fx betyde helt konkret, at interesse for elevers ensomhed, mulige mobbepositioner og social trivsel i skoleklasserne også vil være investeringer i de enkelte børns trivsel og udviklingsmuligheder.

Lærerens interesse for den generelle trivsel i klassen kan udvides med et blik for, hvordan unge der er i særlige vanskeligheder kan få den yderligere støtte udefra, som der er brug for. Den dobbelte interesse for den almene psykosociale kultur i klassen og blikket for individuelle problemstillinger, som kalder på særlig opmærksomhed og eventuel mentor-ordning, peger på at fortrolige voksne i skolens faglige og sociale liv er voksne, der udviser professionelt nærvær.

De to hovedbehov for fortrolighed med andre voksne end forældre som beskrevet ovenfor kan evt. praktiseres ved dels at tilbyde efteruddannelsesforløb af alle lærere og pædagoger, hvor der deles viden om, hvordan denne mere generelle adgang til fortrolighed kan udmøntes i skolehverdagen. Og dels ved evt. at optimere og synliggøre kommunens mentorordninger for unge. 


\section{Empirien der informerer denne rapport}

Rapportens konklusioner hviler på et bredt empirisk materiale - dels et baggrundsmateriale og dels et ny-indsamlet materiale foretaget $\mathrm{i}$ forbindelse med opgaven "En fortrolig voksen". Baggrundsmaterialet udgøres af forskernes egne tidligere undersøgelser på feltet, som er blevet genbesøgt og gen-analyseret med henblik på at afdække hvad de unge forstår ved fortrolige professionelle voksne, hvem af de unge der har brug for en fortrolig professionel voksen, og hvad de efterspørger fra deres professionelle voksne. Det materiale der er blevet gen-analyseret stammer fra eXbus-projektets forskning (exploring bullying in schools) fra 2009-2011 (Kofoed \& Søndergaard 2013), og særligt "Vestegnsundersøgelsen" en survey med 1.052 elever fra 7-8 klasse 20092011 (Hansen, Henningsen og Kofoed 2013). Eleverne i denne survey har bl.a. erklæret sig enige eller uenige i udsagnene: "Jeg kan altid regne med mine forældre". "Jeg stoler på de voksne i skolen" og "Der er voksne i skolen jeg kan tale med, hvis jeg har problemer". Fra Jens Christian Nielsens forskning trækkes der i særlig grad på undersøgelsen "Når det er svært at være ung i DK", der både kvantitativt og kvalitativt undersøger subjektiv trivsel, sociale relationer og mistrivselsrelaterede emner (Nielsen \& Sørensen 2010, Sørensen m.fl. 2011). Desuden gøres brug af viden fra projektets særkørsler, der behandler betydningen af at have betroet sig til nogen når man er sorgramt (Nielsen m.fl. 2012). Og der trækkes på materiale fra forskellige trivsels- og fritidslivsundersøgelser foretaget i regi af Center for Ungdomsforskning. Fra Ditte WintherLindqvists forskning er det interviewundersøgelsen om unge med en alvorligt syg forælder. Projektet er finansieret af og udført i regi af organisationen Børn, Unge og Sorgs forskningscenter og udgøres af 37 interviews med teenagere der fortæller om livet med en alvorligt somatisk syg forælder, herunder hvem de støtter sig til og hvem de taler med om deres situation og problemer.

Den ny-indsamlede empiri består essays/stile fra fem 8. klasser fra skoler i Gentofte kommune i starten af 2015, som er blevet stillet spørgsmålet: Hvad forstår du ved en fortrolig voksen? og/eller hvad er en voksen, du kan stole på? Elevernes essays er analyseret ud fra, hvilke voksne de udpeger som fortrolige, hvad de forstår ved fortrolighed, hvad de mener, er forudsætninger for fortrolighed og hvad de er fortrolige med hvem om. Endelig er analysen af essay-opgaverne blevet sammenlignet med fund fra baggrundsempirien med henblik på at sammenligne, hvor stor overensstemmelse der er på tværs af de forskellige empiriske kilder. Herudover er der foretaget et gruppeinter- 
view med unge fra en ungdomsskole om, hvad deres erfaringer er med professionelle fortrolige voksne og hvilken rolle mentor-ordningen spiller for deres trivsel og mistrivsel. De unges egne stemmer og perspektiver er således hovedstenen i den ny empiri. For også at undersøge de professionelle voksnes perspektiver, er der foretaget et fokusgruppeinterview med 6 deltagere fra Gentofte Kommune: skoleledere, skolelærere og lærere med særlige ressourcefunktioner. De blev spurgt om, hvad de fra deres perspektiv opfattede som særlige udfordringer i ungeliv i dag og bedt om at nævne konkrete episoder, hvor de havde haft elever der efterspurgte fortrolighed og udforske dilemmaer i forhold til at være i rollen som fortrolig voksen med de unge i skole-regi. For at udvide vores indsigt i, hvordan mentorer udenfor skolens regi skaber fortrolighedsrelationer til udsatte unge har vi fulgt en beskæftigelsesmentor igennem to arbejdsdage og her overværet samtaleinteraktioner med 6 unge.

\section{En fortrolig voksen - analyse af forskernes egen empiri: med unge der har en syg forœlder, trivselsundersøgelsen og vestegnsunder- søgelsen, inkl. børn med mobbeerfaringer}

Helt generelt må det konstateres at lærere som fortrolige voksne, er en sjældenhed i vores empiriske materiale fra udskolingsfeltet.

De konklusioner der kan drages fra analyserne peger i retning af en treleddet opdeling af de unge. Denne deling kan bruges til at få øje på forskellige behov hos de unge for en fortrolig voksen uden for hjemmet, og til at pege på hvilke forventninger de unge har særligt til deres lærere.

1. Stærk voksenforankring: Det er unge som er relationelt godt forankret i stærke netværk med voksne, primært med en eller begge forældre og andre ressourcepersoner i privatsfæren (gode venners forældre, øvrige familiemedlemmer (bedsteforældre, mostre/tanter/onkler).

2. Spinkel voksenforankring: Det er unge som har en enkelt eller to voksne i deres liv som de er fortrolige med (den ene/begge forældre og en enkelt øvrig ressourceperson (tidligere lærer fra efterskolen, klasselæreren, en læge, en præst).

3. Fravær af voksenforankring: Er de unge som alle steder savner forankring i netværk med voksne (både inde og ude af familien). Sidstnævnte gruppe kan så underopdeles i 3a) de der så til gengæld har gode relationer til jævnaldrende, og 3b) de som hverken har stærke og tætte relationer til voksne eller til jævnaldrende. 


\section{Unge i det grønne, gule og røde felt}

Det er alle de unge i gruppe 3, som har det sværest, og som må tænkes at være i søgelyset for en særlig opmærksomhed og indsats. De unge i gruppe 1 og 2, som egentlig har fortrolige voksne i deres liv, kan også i perioder have brug for adgang til fortrolige professionelle voksne, hvis/når der er opbrud i relationer til jævnaldrende eller perioder med problemer der vedr. deres skole- og ungeliv. Fra et interventionsperspektiv kan man sige at de unge i gruppe 1 (unge med stærk voksenforankring) befinder sig i et grønt felt, hvor det primært handler om arbejde forebyggende og trivselsfremmende, så de unge trives socialt og ved hvem de kan henvende sig til, hvis de skulle få problemer, de unge i gruppe 2 (unge med spinkel voksenforankring) er i et gult felt, hvor der både kan arbejdes forebyggende og trivselsfremmende på et generelt plan samtidigt med at det afsøges om de oplever at mangle fortrolige voksne, og de unge i gruppe $3 \mathrm{i}$ et rødt felt, når det kommer til behovet for at voksne professionelle stiller sig fuldt til rådighed som fortrolige i de unges liv. Unge i det røde felt (unge med fravær af voksenforankring) kan alt afhængig af situationen få brug for støtte af mentorer eller kontaktpersoner uden for skolen.

\section{Hvem er de unge fortrolige med om hvad?}

Når det vedrører spørgsmålet: Hvem er de unge fortrolige med? Så kommer forældre og nærmeste øvrige familie ind på forreste række og/eller venner. Relationer til voksne professionelle indtager en sekundær rolle både i praksis og i de unges egne ønsker til og vurderinger af, hvad de synes er vigtigst - og hvem de helst kunne tænke sig at være fortrolig med. Ønsker og behov for at benytte professionelle voksne knytter sig til, hvilke typer problemstillinger de unge tumler med, og hvor deres problemer optræder henne. Der er således en barriere for at benytte lærere som fortrolige vedr. problemstillinger der knytter sig til hjemmet, ligesom der ikke er en klar forventning om at professionelle voksne skal intervenere eller inddrages i de problemer. Omvendt gælder det for de typer problemer, der vedrører livet i skolen direkte, fx mistrivsel socialt, mobning eller skolefaglige udfordringer - at der er en klar forventning hos de unge, i alle grupperne, om at læreren stiller sig selv til rådighed for støtte og påtager sig et ansvar for at være med til at afhjælpe problemerne.

Unge i gruppe 1 med stærk voksenforankring får deres behov dækket for fortrolige voksne i hjemmenetværket og oplever ofte ikke et presserende behov for fortrolighed med de voksne, men sætter principielt set stor pris på at have adgang til et fortrolighedsrum, hvis det skulle blive nødvendigt for dem at benytte det. Her lægges vægt på, 
at det er voksne, der kender dem godt og vil dem det godt (de holder af mig og er altid på min side). Samtidig oplever mange, at det egentlig er deres venner, de mest benytter som fortrolige, fordi de føler sig bedre forstået af de jævnaldrende og har mere til fælles med dem. De som oplever et behov for at benytte de voksnes fortrolighed hjemme, udtrykker stor taknemmelighed over at have kærlige og omsorgsfulde forældre at støtte sig til og få gode råd af. Der bliver ikke i denne gruppe unge talt et behov frem for at benytte lærere og andre professionelle som fortrolige voksne, men for de unge der har en syg forælder er der et behov for at der tages særlige hensyn fagligt til deres belastede hjemmesituation ( $\mathrm{fx}$ i forhold til senere afleveringsdeadlines, evt. færre hjemmeopgaver og forståelse for mere mentalt/fysisk fravær i undervisningen).

Unge i gruppe 2 med spinkel voksenforankring ligner gruppe 1, men har et mindre netværk at trække på og er i perioder derfor også mere sårbare for at savne fortrolige voksne. Blandt de unge med en syg forælder kan det betyde at belastningen i familien (under indlæggelse, svære behandlingsforløb/bivirkninger og forandrede relationer til deres forældre) kan gå ud over deres skoledeltagelse på måder der stresser dem meget. Derfor kan behov for ekstra forståelse forstærkes i de perioder, ligesom de mere eksistentielle spørgsmål og behovet for at tale med nogen uden for familien blive større (de søger ofte fortrolighed med lærere, en præst, familiens læge eller en psykolog). Denne gruppe unge er i en art farezone for at havne i gruppe 3 (fravær af voksenforankring).

Unge i gruppe 3a med fravær af voksenforankring. De unge der alle steder savner fortrolige voksne i deres liv, savner dem for alt det voksne alligevel forstår sig bedre på, kan tilbyde af omsorg, og kan rådgive dem om, og som deres jævnaldrende eller søskende har svært ved at tilbyde, eller leve sig ind i. Det gælder fx i forhold til at tage vigtige livsvalg og opleve en daglig opbakning og emotionel støtte fra en voksen. I denne gruppe er det ikke et aktivt fravalg af de voksne (som vi kan se det i nogle tilfælde i gruppe 1), men en mangel på mulighed for at nyde fortroligheden med voksne, som ikke er til at stole på, eller som ikke udviser interesse for det. Nogle unge med svær sygdom i familien havner i denne gruppe, pga. skred i familieroller og overbelastning - andre har ikke haft fortrolighed i relationen i mange år og er fra en familie uden netværk (øvrig familie og forældres venner) flere af sidstnævnte gruppe, kommer fra familier som på forskellige måder og i forskellige niveauer er i kontakt med det kommunale system. Denne gruppe er bestemt $\mathrm{i}$ en situation hvor der er behov for adgang til en fortrolig voksen uden for familien, og unge fra denne gruppe vil have stor glæde af at møde et aktivt initiativ fra professionelle voksne. Særligt når livet med de jævnaldrende (kæreste/venner) er konfliktpræget eller turbulent, hvilket ofte er tilfæl- 
det $\mathrm{i}$ teenageårene. I de perioder er der fare for at de unge i gruppe 3a havner i gruppe $3 b$.

Unge i gruppe $3 b$ med fravær af voksenforankring. De unge i denne kategori er i stor mistrivsel og i statistisk sammenhæng med større sandsynlighed for risikoadfærd (selvmordsforsøg, misbrug, kriminalitet). De er ramt både i hjemmelivet og i ungelivet som marginaliserede, mobbede, ignorerede/overladt til sig selv - både af voksne og jævnaldrende. Det gælder fx for unge der føler sig mobbet og oplever at både lærere og forældre og tidligere kammerater svigter dem. Det gælder også i tilfælde med forældersygdom hjemme, og social tilbagetrækning blandt de jævnaldrende kombineret med professionelle voksne der ikke er informeret om situationen og som overser de unges mistrivsel.

\section{Opsamlende på de unges forventninger til de professionelle voksne.}

Der er dominerende forventninger fra udskolingselever om, at professionelle voksne tager ansvar for at sikre den trivsel der vedrører skolelivet fagligt og socialt. De positive erfaringer er f.eks. kendetegnet ved, at læreren (efter de er blevet indviet i de unges situation) har vist øget lydhørhed overfor at den unges livssituation og udviser fleksibilitet $\mathrm{i}$ forhold til at aflevere lektier til tiden $\mathrm{mm}$.

De lærere der - også af egen drift - har vist omsorg ved at spørge ind til den unges mulighed for at leve op til de fælles deadlines, og de lærere der har stillet sig selv til rådighed for at hjælpe med at disponere tid og strukturere/prioritere $\mathrm{i}$ opgaver fremhæves som særligt hjælpsomme. Også de lærere der har fulgt op på fortroligheden ved løbende at stille spørgsmål som: hvordan går det med dig? Eller hvordan har du det $i$ øjeblikket? (fremfor spørgsmål der vedr. hvordan det går med forælderens sygdoms tilstand) fremhæves som nære fortrolige voksne - fordi spørgsmålene er åbne og også kan besvares med et høfligt "fint nok", de dage den unge ikke magter at tale om det, eller når det faktisk bare går fint. Ligesom at spørgsmålene også kan besvares med et mere uddybende svar, der kan give anledning til at den unge kommer til en afklaring af hvordan det går, og evt. får øje på at der er brug for hjælp/aflastning i forhold til fx praktiske pligter i hjemmet, som kan tage overhånd i forhold til at leve op til skolearbejdet i bestemte perioder (op til eksamen, op til større skriftlige afleveringer osv.). for de unge som oplever mistrivsel socialt og fx bliver mobbet er der en udtalt forventning om at læreren involverer sig og hjælper dem, og en udpræget følelse af at blive svigtet når/hvis det ikke sker (Hansen 2011). 
Fælles for historierne er, at det er fortrolighed der vedrører de unges deltagelse i skolelivet, fagligt og socialt, som de har ønsker og forventninger til at deres lærere hjælper dem med. 


\section{Analyse af empiri indsamlet $i$ forbindelse med projekt fortrolig voksen}

\section{Analyse af 8. klassernes essays om fortrolighed, tillid og voksne}

Fem 8. klasser i Gentofte Kommune har i begyndelsen af 2015 skrevet skoleopgave om, hvad de forstår ved en fortrolig voksen og/eller en voksen, de kan stole på. Bidragene har mange fællestræk, men rummer også forskellige vinkler på og nuanceringer af, hvad en fortrolig voksen er og kan være.

Ud fra de unges karakteristikker af, hvad en voksen fortrolig er og kan være, har vi analyseret os frem til følgende spor i materialet, som fremlægges i kondenseret form efterfulgt af citater fra de unges essays.

\section{Spor 1: Forcldre og anden familie har som regel de unges fortrolighed}

Ligesom det gælder for empirien i baggrundsmaterialet, fremhæves forældrene som de unges betydningsfulde voksne. Det er forældre - eller i nogle tilfælde anden familie der som oftest fremhæves som de voksne, der har de unges tillid og som de anser som deres fortrolige - eller som nogle de forventer en særlig høj grad af fortrolighed med. Det betyder samtidig at store konflikter og evt. tab når det kommer til forælderrelationen må anses for at være særligt belastende for de unge. Især fremhæves mødre som fortrolige voksne, der er lyttende og omsorgsfulde. Dette er tydeligst og mest udtalt blandt pigerne. Flere piger påpeger samtidigt vigtigheden af at kunne betro sig til en af samme køn. Der er også flere af de unge som nævner andre familiemedlemmer som deres fortrolige. Det kan være bedsteforældre som "altid er på min side" eller søskende som er/eller har været i samme situation som en selv, fx også i forhold til eventuelle konflikter med forældre.

- Det er altid rart at have en man kan stole på, en man kan komme til hvis der er sket noget og en man kan søge tryghed hos. Men hvem er det? Jeg har min mor, et perfekt forbillede og en der altid er der for mig. Min mor er min helt. Hun er min klippe og den jeg kan støtte mig rigtigt op ad. Jeg kan ikke stole på mine veninder på samme måde som jeg kan stole på min mor. Hun er den eneste jeg rigtig kan stole på. (Pige 8. kl.) 
- Det har stor betydning for den situation man står i, hvilken voksen man kan stole på, synes jeg. Jeg kommer til min farmor, når jeg har problemer i skolen. Jeg ved, at det er fordi jeg gerne vil have hende til at se det fra min side. (Pige 8. kl.)

- For mit vedkommende kan jeg bedst lide at tale om mine problemer med mine søskende, fordi de måske kender den situation som jeg sidder i. Faktisk føler jeg mig mere fri når jeg taler om mine problemer med mine søskende. (Pige 8. kl.)

- Jeg synes, det er vigtigt at have nogle, man kan stole på. Nogen man ved, der altid vil være der for én. Nogen man kan tale med om alt. Nogen der lytter. De behøver ikke at kunne hjælpe til, men bare være der. Hvis jeg hverken havde min familie eller mine venner til at vare der for mig, så ville jeg bryde sammen. (Pige 8. kl.).

\section{Spor 2: Nogle emner er lettere at tale med jœvnaldrende om, men måske kan voksne bedre hjœlpe}

Der er dog grænser for fortrolighed med mor og far, fx kan det være vanskeligt og føles akavet at tale med forældre om kærester, intime og seksuelle emner. Her fremhæves i stedet venner, men også søskende, som de fortrolige og som nogle der kan have lettere ved at forstå en, fordi de selv står i og har været i samme type situation. Selvom emnet for essay-opgaverne handler om fortrolige voksne, er det bemærkelsesværdigt, at mange elever samtidigt fortæller om, hvor betydningsfulde deres venner er for dem. Venner og venskaber er en central del af ungdomslivet, og de fleste unge har og er i tætte venskabsrelationer til andre unge. Relationerne til venner begynder også ofte i ungdomsårene at erstatte familien som den centrale kontekst for unges sociale liv og udvikling. Omvendt betyder det også, at hvis unge ikke har sådanne tætte relationer, kan det være et tegn på, at de ikke er særligt godt integreret i ungdomslivets fællesskaber. Selvom flere unge peger ud, at fordelen ved at tale med venner er, at de bedre forstår en, så er der også flere som påpeger, at der er voksne, som har erfaringer og viden, der gør dem bedre i stand til at hjælpe og rådgive.

- Mange børn går måske til deres venner og veninder, i stedet for til en voksen, hvorfor det? Måske fordi de synes det er akavet, at snakke om personfølsomme ting med deres forældre. (Dreng 8. kl.)

- Det er nemmere at betro sig til jeonaldrende. Men problemet ved at betro sig til en ven/veninde kan være, at de ikke kan være så gode til at hjælpe og rådgive, fordi de ikke er lige så modne og har lige så mange erfaringer som voksne. (Dreng 8. kl.) 


\section{Spor 3: Fortrolighed krœver tillid til, at man ikke bliver udstillet}

En fortrolig voksen er en person der holder tæt. Fx bliver diskretion fremhævet som en absolut forudsætning for at de unge vil betro sig til den voksne. Eleverne peger på vigtigheden af, at de også kan stole på, at den voksne ikke fortæller noget videre efter sådanne samtaler - uden deres samtykke. De føler sig svigtet og udsatte, hvis intimitet brydes og personlige problemer bliver fortalt videre. Lærere tales kun i et mindre omfang frem som tilgængelige for fortrolighed, og når de tales frem er det med forventning om, at det fortrolige ikke deles med de andre elever.

- Jeg tror det er vigtigt, at have en voksen man kan stole på. En voksen der ikke vil sige noget fortroligt videre. (pige 8. kl.).

- Ulempen ved lærere og pædagoger kan være, at de har en form for magtposition. Fx hois de voksne føler, at de skal fortælle barnets problemer til andre voksne eller kollegaer, så er fortroligheden brudt. (Dreng 8. kl.)

\section{Spor 4: En fortrolig voksen står til rådighed for respektfulde samtaler om nœsten alle emner}

Det fremgår, at for at være gode fortrolige voksne i de unges øjne, kræver det både en kvantitativ og kvalitativ dimension. De voksne skal på den ene hånd være tilgængelige og til at få fat på for de unge, når de har behov for at tale om det, der ligger dem på sinde og det skal være en "man kan tale med om alt" - eller i hvert fald de fleste emner. På den anden hånd skal de voksne også kunne tale med de unge på en måde, hvor de unge oplever at der bliver lyttet til dem og de voksne forsøger at forstå deres perspektiv samt behandle den viden de har fået med fortrolighed.

- For mig er en fortrolig voksen, en der kan hjælpe med at forstå ens følelser og reaktioner. Det er en man kan betro sig til og fole sig tryg ved. Men det er ogsa vigtigt, at det er en voksen, som har forståelse for hvad den unge går i gennem, og kan hjælpe den unge på vej. (Pige 8. kl.)

- Det at have en person, der lytter, forstår og respekterer, kan betyde en hel del. En voksen man stoler 100 pct. på, er som en slags skraldespand til bekymringer og ting der er svære at få sagt. (Pige 8. kl.)

- En man føler sig tryg hos og føler at man kan tale om alt med. En der kan holde tæot med det man fortæller og en man ser frem til at være sammen med. En man kan grine og græde med, en man kan sidde ién time ved siden af uden at sige noget til hinanden, og ikke synes per- 
sonen er kedelig. En der ikke dømmer en for ikke at være perfekt, men som derimod respekterer en. (Pige $8 . \mathrm{kl}$.)

\section{Spor 5: En fortrolig voksen skal helst kende én, men det modsatte kan også vœre en styrke}

Mange påpeger vigtigheden af, at den voksne kender og har interesse og engagement $\mathrm{i}$ den unges liv og udfordringer. Det kendetegner forældrene som fortrolige voksne, i de fleste tilfælde, men det kan også være andre fortrolige, der viser en vilje til at ville investere noget af sig selv i forholdet. Omvendt kan det også være et problem, at forældre kan være eller let blive bekymrede og på den måde, hvilket begrænser hvad de unge vil fortælle dem. Enkelte af de unge beretter også, at der kan være styrke ved fx at gøre brug af en anonym rådgivning, hvor man ikke sidder overfor den voksne faceto-face og hvor den voksne den unge betror sig til ikke har en forudfattet holdning til den unge eller samtidig er i en position til også fagligt at bedømme den unge.

- Det vigtigste for fortroligheden mellem et barn og en voksen er, at det er en voksen som er vant til at omgås og være sammen med barnet $i$ dagligdagen, og som også holder af barnet.

(Dreng 8. kl.)

- At vide, at en person ville gribe mig, hvis jeg faldt. Ville fä mig op, hvis jeg nåede bunden. Det ville være en, jeg kunne stole på. En der kender mig, forstär mig og ved, hvad jeg kan både på det sociale og faglige plan. Jeg ved, at det er vigtigt for mig, ikke at føle ubehag ved at snakke om mine følelser eller åbne mig for vedkommende. Skulle det ske, at mine tanker eller problemer ikke blev taget seriøst nok, ville jeg uden tvivl blive flov og usikker. Jeg ville hurtigt miste tilliden, og trække facaden op igen. Måske ville jeg endda aldrig kunne stole på personen igen. Jeg skal føle mig speciel og mine problemer og behov skal prioriteres rigtig højt, før jeg har en voksen at stole på. (Pige 8. kl.)

- Det at kende en person for man betror sig til vedkommende, er yderst vigtigt for mig. Jeg ville aldrig kunne åbne mig for en fremmed, som jeg kan, overfor en voksen som jeg kender, for når jeg ved, at jeg skal til at give noget, vil jeg også have noget igen, og lige pludseligt bliver alt taget mere seriøst, fordi der nu er noget at holde på for begge parter. (Pige 8. kl.)

- Når man skal stole på en voksen, er det vigtigste at personen er fortrolig overfor én. Man behøver ikke at kende personen, hvis personen viser at han eller hun er fortrolig. (Pige 8. kl.)

Endeligt er der unge som peger på, at de slet ikke ønsker en fortrolig voksen, men det er så sjældent at vi ikke har tildelt denne gruppe et eget analyse-spor. Blandt disse unge opfattes voksne som fra en helt anden verden end unge, og som nogle der bare har 
svært ved at forstå dem. Eller de unge har så stor mistillid til voksne, at de synes det er for sårbart at gøre sig fortrolige med nogen.

- De voksne siger altid, at man kan stole på dem. Det kan bare være svært at stole på en person som ikke rigtig lytter. Det er i hvert fald ofte svert at tale med en der ikke lytter. Jeg synes til tider, at de voksne ikke lytter. Hvis jeg stoler på en, er det nok min mor, men alligevel kender hun ikke alt bag min lukkede dør. Jeg deler ikke mine hemmeligheder med alle. Jeg deler dem slet ikke med alle voksne. Det er for skrøbeligt. (Pige 8. kl.)

- Jeg vil nok aldrig komme til at synes om at stå $i$ den sårbare situation, at en voksen kender alle ens hemmeligheder... Altså så min konklusion er at der ikke er en voksen jeg kan STOLE PÅ, og det er jeg på en måde glad for. (Pige 8. kl.)

I forhold til hvor markant skolens fagprofessionelle (skoleledere, skolelærere og lærere med særlige ressourcefunktioner) talte unges problemer med skole- og præstationspres frem i fokusgruppeinterviewet, undrer det os, at ingen elever har skrevet om skolepres og præstationsproblemer som oplagte emner at tale med fortrolige voksne om i skolen (jvf. Piger i Pres). Om det skyldes opgaveformuleringen, om det skyldes en individualisering af problemet (Det er bare mig der ikke kan fä det til at hænge sammen) eller andre forhold kan vi ikke vide, men vi opfatter ikke fraværet af tematikken, som et udtryk for at problemet er fraværende i de unges liv. Måske er det et tema de professionelle voksne selv skal være aktive på for at få i tale?

\section{Analyse af gruppeinterview med elever fra ungdomsskolen}

De interviewede elever fra ungdomsskolen placerer sig i kategorierne 2 (spinkelt voksenforankring) og 3a (fravær af voksenforankring). dvs. deres netværk til voksne er svagt, hvilket svarer til at de i et interventionsperspektiv tilhører det gule og røde felt. Den ene har en forælder hun er fortrolig med, den anden savner voksne i privatsfæren - han kan betro sig til og være fortrolig med. De interviewede unge opfatter sig selv som nogle der har brug for yderligere støtte end den der tilbydes indenfor den almindelige lærer-elev relation. De sætter stor pris på at mentoren er meget proaktiv i sin måde at deltage i deres liv på (ringer og bemærker at de ikke er kommet $i$ skole) og står til rådighed uden for almindelig arbejdstid (jeg kan altid ringe til min mentor, også kl. $2 \mathrm{om}$ natten). Det at netop de interviewede unge (fra gruppe 2 og 3) har brug for særlig støtte, svarer godt overens med de elever fra gruppe 1, som genkender behovet som særligt relevant for de unge, der ikke har forældre de kan tale med og som tager vare på dem. Relationen til mentoren er kendetegnet ved at mentoren møder dem på et andet grundlag og med andre støttemuligheder. Det betyder også at mentoren opleves som 
en der møder dem som en person, frem for en elev, eller en pligtopgave. "Mentoren er gået ind $i$ det her job for at hjælpe de unge, hvor ( $X$ en af deres lærere) er gået ind $i$ det her job for at lære de unge noget". Mentoren er opsøgende, engageret og undersøgende snarere end dømmende og klar til at gå ind i mere private problemstillinger på den unges side, fx i relation til konflikter derhjemme. Eleverne har stor glæde af deres mentor og omtaler denne med særligt positive ladede superlativer og det er tydeligt at relationen opleves som kærlig frem for neutral. Relationen til andre professionelle voksne fremhæves også i interviewet. De er glade for når deres almindelige lærere udviser opmærksomhed og omsorg for dem på en god måde:

"Lærer $X$, gør det på sådan en elegant måde. sådan så det ikke er sådan lige når man træder ind af døren, men at vi bliver bedt om at gå ud i gruppearbejde og så kommer hun lige hen og lige siger "Hey, kan du ikke lige hjælpe mig med noget...".

At læreren er diskret og ikke får udpeget den unges problem for alle de jævnaldrende er fuldstændigt afgørende og helt på linje med hvad eleverne i 8. klasserne også konsekvent taler frem i deres essays, som en voksen man kan og tør stole på.

\section{Barrierer for at betro sig til professionelle voksne}

Uanset graden af behov, så synes der at være nogle barrierer for at betro sig til voksne, som vedrører den sårbarhed det involverer at betro sig til nogen i det hele taget, og dernæst til at betro sig til bestemte andre. Det kan være en overvindelse at indrømme overfor sig selv at man er ramt så hårdt at man ikke kan løse problemerne helt alene og at man har brug for at dele det med nogen. Oven i det kommer så den tillid der er nødvendig for at de unge tør stole på de voksne. At betro sig til nogle man kender, men som er uden for familien, kræver også en tillid til at betroelsen ikke får negative konsekvenser - og det kan være en vanskelighed i relationen til lærerne, fordi lærerne er en faglig bedømmer af dem. En fortrolig voksen, er ifølge vores unge informanter en der ikke siger det delte videre til andre, og en der er diskret omkring den personfølsomme information (det er en man kan stole på). Her er der en udpræget bekymring omkring at blive udstillet socialt. For mange er en fortrolig voksen også en der er i stand til at handle på situationen og være med til at løse problemerne, hvilket kan være en del af forklaringen på, at problemer der knytter sig til livet i familien, ikke (så ofte) opleves som relevant at inddrage ens lærere i - ligesom de unge kan føle sig ansvarlige/skyldige og ikke vil udstille deres familie. Men der er også den betydelige barriere, at nogen af de unge med problemer derhjemme, ser skolen som en mulighed for frirum fra de belastninger og bekymringer de bokser med derhjemme. Det frirum er særlig tydelig i materialet fra de unge med en alvorligt syg forælder, som oplever at det er svært at opretholde et frirum i skolen, når de først har fortalt om deres problemer til 
lærere og kammerater. Den type opmærksomhed og omsorg der er ment som en hjælp og støtte, fx hvordan går det med din far?, kan nogle gange forhindre de unge i at have et sted hvor de ikke konfronteres med deres situation hjemme. Mange vælger af samme grund ikke at fortælle om problemerne hjemme til de professionelle voksne og nogle trives godt med det (unge fra gruppe 1 og 2), mens andre savner et fortrolighedsrum med nogen (unge i gruppe 3). Den fuldstændige tillid skrives frem som en forudsætning for fortrolighed. Overalt i materialet fremhæves de voksnes diskretion som værdsat og forstærkende for, at de unge vil betro sig.

\section{Fortrolighed i mellemrum}

Når vi analyserer materialet for hvor og hvornår de unge benytter professionelle voksne som fortrolige, så sker det ofte i det man kan kalde for mellemrum, dvs. mellem timer, i pausen før og efter timen, på gangen, lige udenfor eller på vej et sted hen. En del unge forklarer, at de ikke betror sig til en lærer, hvis ikke der er fuldstændig tillid til, at andre ikke får det at vide, og det må derfor foregå uden for klasserummet eller andre plenumsituationer. Mange af de snakke der opstår, er ikke planlagt, og den unge har ikke på forhånd besluttet sig for at tale med den voksne, men muligheden opstår og så sker det. Denne spontane måde fortrolige samtaler opstår på, understøttes også af, at mange unge lægger vægt på at fortroligheden er et frivilligt og lystbetonet anliggende, og ikke noget der kan afkræves af dem. I praksis betyder det også, at de professionelle voksne bør være opmærksomme på at travlhed i mellemrum, kan forhindre at fortrolighed opstår, og være en barriere for at der optræder opfølgende dialoger om hvordan den unge går og har det.

\section{Uklarhed om lœrerfagligheden i forhold til at vœre en fortrolige voksne for de unge}

De unges forventninger til professionelle voksne peger ind i og må ses i dialog med de professionelle voksnes egen faglige selvforståelse. Her ser der ud til at være uklarhed og opbrud i samfundets forventninger til lærerens rolle og lærernes egen selvforståelse. Der er et spændende skisma mellem faglig (lærer) identitet og det at være social ressourceperson for de unge. Her finder vi, at diskursen om den professionelle distance i pædagogisk arbejde, som har været en udbredt i 90érne og 00'ernes pædagogiske landskaber spiller ind (Sanderhage 2008, Hjort 2005). Ideen om professionel distance handler om at det professionelle pædagogiske arbejde altid involverer den personlige indleven og medleven i de samspil den professionelle indgår i. Når man i det 
pædagogiske arbejde bruger sig selv som redskab (empati, personlige erfaringer, medleven) og er involveret $\mathrm{i}$ at have ansvar for andre menneskers trivsel og udvikling, så opstår der diskussioner af, hvordan man kan passe på sig selv som fagperson i processen. Heraf skabes diskurserne om at sondre skarpt mellem det private og det professionelle i rollen som fagperson. For nogen kan det betyde, at der sættes lighedstegn mellem det at være professionel og at være distanceret fra de unges problemer, og der opstår bekymring for om den professionelle bliver "over-involveret". I forhold til dette skisma, er der en tendens til at der optræder forskellige positioneringer i feltet. Nogle lærere positionerer sig som "fag-faglige" lærere, andre primært som lærere der engagerer sig i elevernes sociale dannelse, og endelig er der de lærere som positionerer sig som både-og i deres faglighed.

\section{Professionelt nœrvœr i lœrergerningen}

Vi vil gerne foreslå en nuancering mellem det private og professionelle med begrebet om det professionelle nærvær, som anbefaling og modbillede til den professionelle distance. Det professionelle nærvær er ikke et privat nærvær, men involverer de psykosociale sider af fagligheden som peger tilbage ind i den faglige kerneopgave læreren har. Det knytter sig til at bringe personlige erfaringer og vurderinger i spil i forhold til at være med-deltager $i$ at bidrage til de unges faglige udvikling og trivsel. Det handler om at stille sig til rådighed for at møde den unge, der hvor vedkommende befinder sig, og prøve at bidrage til dennes udviklings- og trivselsmuligheder i skolen. Professionelt nærvær handler også om at lytte, give råd og vise den unge opmærksomhed. Fx ved at sige: "Hvis der er noget du har brug for at tale om, eller brug for hjælp med at håndtere, så kan du komme til mig med det". Det kræver på den måde et aktivt initiativ, ligesom det kræver respekt for, at den unge kan afvise tilbuddet om at betro sig eller vise tillid. Det handler ikke om at være privat med den unge. Hvad det professionelle nærvær betyder, er tydeligere beskrevet som en særlig kompetence i det socialpædagogiske arbejde, end i lærergerningens fag. Med den øgede opmærksomhed på vigtigheden af opgaven, og politiske krav om at samfundet må tage et fælles ansvar for børns/unges trivsel - er der opstået et øget behov for at lærerens psykosociale kompetencer og indsatser italesættes og bliver integreret i alle læreres faglige identitet. Det professionelle nærvær er forebyggende og relaterer sig til de indsatser der vedrører alle (inklusiv de unge i det grønne felt fra gruppe 1 med stærk voksenforankring), ligesom det involverer at stille sig til rådighed i de tilfælde hvor der er særlige udfordringer for enkelte unge. Det kan være ved at involvere sig når børn og unge rammes af sociale begivenheder - f.eks. forældre i skilsmissekonflikt, sygdom i familien eller mobning i klassen som påvirker de unges sociale og faglige deltagelse og trivsel i skolen. Det er netop den 
type problemstillinger, de unge har med skolelivet, som de udtrykker forventninger om, at deres lærere hjælper dem med.

\section{Rum for dialog med unge om ungdomslivets udfordringer og mistrivsel}

Vi anbefaler, at udvise forståelse for de sociale rammers betydning for unges livsduelighed og trivsel. Løsning og håndtering af unges mistrivsel skal ikke nødvendigvis alene findes hos den unge selv. Det handler også om, hvordan den unge er integreret og trives i de sociale sammenhænge, hun/han indgår i og er del af eller ikke er del af. Som voksen kan man ikke løse alle trivselsproblemer, men man har mulighed for at være med til at initiere et større socialt og kollektivt fokus på unges trivsel og mistrivsel i de sammenhænge unge indgår og bevæger sig i. En sådan interventionsform afspejler en kontekstuel udviklingsforståelse. Det betyder, at den unge ikke kun aflæses som en type eller som en særlig personlighed med bestemte uforanderlige træk og tilbøjeligheder - men som en person der ikke er uafhængig af de betingelser voksne, venner og samfund udgør for dem. Fordelen ved at forstå unge på den måde ligger i, at forebyggelse og foregribende indsatser faktisk giver mulighed for at skabe positive forandringer for de unge, når de støder på udfordringer de har vanskeligt ved at håndtere.

Det ser ud til, at der eksisterer et behov for at skabe rum for dialog med og blandt unge om ungdomslivets krav og udfordringer, fx krav om at være og fremstå som en multipel succes på alle fronter (uddannelse, krop, udseende, venner, popularitet osv.). Sådanne former for dialog med unge kræver også at man arbejder for at skabe trygge rammer (i ungdomslivets fællesskaber), hvor unge har mulighed for, og ikke oplever det som farligt, at have dialog med andre unge om følelser og forhold i livet, hvor de fremstår sårbare. Det handler også om at opfordre unge til at støtte hinanden, og hjælpe de unge til selv at aktivere deres netværker ( $\mathrm{fx}$ til andre fortrolige voksne) hvis der opstår problemer og mistrivsel i en periode.

Vi kan på baggrund af ovenstående betragtninger ligeledes anbefale, at man taler om unge i sårbare positioner frem for at tale om sårbare unge. Der er unge som kommer ind i ungdomslivets fællesskaber med forudsætninger, der gør dem sårbare eller den anden vej rundt, at de indgår i fællesskabssammenhænge, der gør dem sårbare. Her er der brug for, at fagprofessionelle voksne vender blikket fra problematikker som værende alene den enkelte persons og afsøger om der er praksisser og mønstre i fællesskabet, der skal arbejdes med. Eksempelvis kan man måske få et mere nuanceret blik for, at en elev reagerer passivt, aggressivt eller med skoleulyst (Hansen 2014), fordi han/hun for eksempel bliver presset på nogle bestemte måder af de andre i klassen. 
Derfor er det relevant at se på kulturen i klassen og fokusere på at udvikle en pædagogisk praksis, der kan hjælpe alle til at trives bedre.

\section{Professionelt nœrvœr og sœrlige indsatser}

Der er en tendens i den sociale sektor (inklusiv blandt sundhedsfagligt ansatte) til at almindelige udfordringer og problemer som unge kan have, betragtes som problemer, der kræver særligt psykolog- eller terapeutisk ekspertise at håndtere (Brinkman 2010). Det betyder, at nogle lærere ikke oplever sig rustet (fagligt og personligt) til at være fortrolige voksne for de unge. Kobles denne tendens med en legitim henvisning til den professionelle distance som en forholde-sig måde der netop er særligt professionel, så bliver resultatet at nogle lærere ikke ser det som deres opgave at være fortrolige voksne for de unge. Omvendt sker det, at andre lærere som modstykke indstiller sig på at involvere sig fuldt ud i de unges problemer, måske også på mere terapeutiske måder, og faktisk risikerer, at bevæge sig ud i semi-psykologiserende samtaler uden at have den rette psykologfaglige viden. Begge tendenser vurderer vi som uheldige. Vi ser en vigtig pointering i det beskrevne begreb om professionelt nærvær som betegnelse for at alle professionelle voksne bør se sig selv som ansvarlige medspillere i de unges trivsel i skolelivet og herigennem også som potentielt fortrolige voksne for de unge. Kun i nogle tilfælde vil der være behov for en mere psykologisk baseret intervention eller særlige støtteordninger - og i de tilfælde består lærerens opgave i at få henvist den unge videre til særlige mentor ordninger, eller til specifikke professionelle behandlere. Den gruppe unge som har stort behov for fortrolige voksne uden for familien (unge i det røde felt med fravær af voksenforankring) har ofte et behov der overskrider, hvad der kan forventes og håndteres indenfor den almindelige lærer-elev-relation, $\mathrm{fx}$ at kunne blive ringet op uden for almindelig arbejdstid. Det er dog fortsat en psykosocial almen opgave for den professionelle nærværende lærer at udvise særlig opmærksomhed overfor de unge der i perioder har brug for det (unge fra det grønne og gule felt med henholdsvis stærk og spinkel voksenforankring), og få øje på de unge der har behov for yderligere støtte. 


\section{Do's and don'ts}

\section{Gode råd til lœrere og skolepœdagoger der gerne vil vœre tilgœngelige som fortrolige volksne}

På baggrund af en kontekstuel udviklingsforståelse og empirien der informerer denne rapport har vi udarbejdet følgende 8 konkrete råd til skolelærere og skolepædagoger:

1) Integrér det faglige undervisningsarbejde med den psykosociale indsats for at udvikle tolerant og rummelig skoleklassekultur.

2) Inddrag elevernes forslag og ideer til at skabe et positivt socialt fællesskab og forebygge mobning i elevgruppen.

3) Hold øje med elever der ser ud til at være meget alene. Er de ensomme? Er de udenfor? Og hvordan kan de blive integreret (igen)?

4) Vær opmærksom på, om der er elever under studiepres. Skal de have hjælp til at prioritere deres arbejde? Skal de i en periode have færre lektier for? Skal de øve sig i ikke at stille for høje krav til sig selv?

5) Reager på din bekymring for en elev. Vær ikke bange for at tage første skridt og henvend dig til den unge med dine iagttagelser. Er der brug for mere omfattende støtte, så henvis den unge videre og følg op på hvordan det går med den unge.

6) Unge, der umiddelbart genkendes som velfungerende kan også have brug for særlig opmærksomhed i perioder. Der findes ingen standarder for hvordan man skal gribe det an. Undersøg hvordan eleven har det og brug spørgsmål og dialog med eleven til at finde en vej. Vis at du er der.

7) Professionelt nærvær må kombineres med professionel diskretion *).

8) Undgå kønsblindhed. Selvom mistrivsel stadig følger visse kønsmønstre, passer alle ikke ind i mønstrene. En dreng kan også cutte sig ligesom en pige kan have misbrugsproblemer eller være ude i spilleproblemer på nettet.

*) her berøres en gråzone op mod den udvidede underretningspligt, som lærere og pædagoger har i henhold til Lov om Social Service. Her kan fortroligheden iagttages på den måde, at læreren og pædagogen gør eleven opmærksom på, at den information den unge har givet SKAL gives videre til de sociale myndigheder. Eleven kan herefter inddrages mest muligt i processen.

Læs mere om, hvordan voksne kan spotte, afkode og gribe ind i unges mistrivsel i bogen Det er svært at være ung. 10 eksperter om unges trivsel og mistrivsel. 


\section{Litteraturhenvisninger}

Bach Ludvigsen, N. \& J. C. Nielsen (2008): Unges tryghed og trivsel i Frederiksberg Kommune. Aarhus Universitet.

Brinkmann, S. (2010) (red.): Det diagnosticerede liv. Sygdom uden grænser. Forlaget Klim.

Hansen, R. H (2014): "Vi går langt for vores pals": om skolemodstand, fællesskabsforståelser og mobning. I Nye perspektiver på mobning: PPT, 2014. s. 50-55 (Den blå serie; Nr. 31). Nr. Temanr., Vol. 51).

Hansen, R.H, I. Henningsen \& J. Kofoed (2013): Når klassekultur tipper over i mobning. I J. Kofoed; D.M. Søndergaard (red.) Mobning gentænkt. Hans Reitzel, 2013. s. 2155 .

Hansen, H.R. (2011): Lærerliv og elevmobning. Ph.d.-afhandling 252 s. København. Aarhus Universitet, Institut for Uddannelse og Pædagogik (Campus Emdrup).

Hendry, L. B. \& M. Kloep (2012): Adolescence and Adulthood. Transitions and Transformations. Palgrave MacMillan.

Hjort, K. (2005): Professionaliseringen i den offentlige sektor. Roskilde Universitetsforlag.

Illeris, K., N. Katznelson, J. C. Nielsen, B. Simonsen \& N.U. Sørensen (2009): Ungdomsliv. Mellem individualisering og standardisering. Samfundslitteratur.

Kofod, A. \& J. C. Nielsen (2005): Det normale ungdomsliv. Hverdagsliv, frllesskab, trivsel og fremtid. Danmarks Pædagogiske Universitet.

Kofoed, J. \& D. M. Søndergaard (2013) (red.): Mobning gentænkt. Hans Reitzels Forlag.

Mørch, S. (2010): "Ungdomsforskningen som perspektiv og mulighed", i Psyko \& Logos, nr. 1/10. TEMA: Ungdom og de unges liv. Dansk Psykologisk Forlag.

Nielsen, J. C., N. U. Sørensen og N. M. Osmec (2010): Når det er svært at være ung i DKunges trivsel og mistrivsel $i$ tal. Aarhus Universitet.

Nielsen, J. C., N. U. Sørensen, N. Katznelson \& M. D. Lindstrøm (red.) (2010a): Den svære ungdom. 10 eksperter om unges trivsel og mistrivsel. Hans Reitzels Forlag. 
Nielsen, J. C., N. U. Sørensen \& N.-H. M. Hansen (2012): Unge pårørende og efterladtes trivsel. En analyse af trivsel og mistrivsel blandt unge, som har oplevet alvorlig sygdom eller dødsfald i nærmeste familie. Aarhus Universitet.

Nielsen, J. C. \& N. U. Sørensen (2012): Når det er svært at være ung $i$ DK - viden og råd om unges trivsel og mistrivsel. Aarhus Universitet.

Sanderhave, T. (2008): Pædagogik læring udvikling og forandring. Hans Reitzels Forlag.

Sørensen, N. U., A. Grubb, I. Warring Madsen \& J. C. Nielsen (2011): Når det er svært at være ung i DK-unges beretninger om mistrivsel og ungdomsliv. Aarhus Universitet.

Winther-Lindqvist, D. (2010): " På tærsklen til et ungdomsliv - social identitet og fremmelighed", i Psyko \& Logos, nr. 1/10. TEMA: Ungdom og de unges liv. Dansk Psykologisk Forlag. 

Fortrolige voksne i de unges liv belyser unges behov for og forventninger til fortrolige voksne. Rapporten har scerligt fokus på den del af unges tilvœrelse, der byder på negative udfordringer og hvor der kan vare behov for at få adgang til en fortrolig voksen.

De fleste unge fremhœver i høj grad deres forcldre og andre voksne fra den private sfœre, som deres foretrukne fortrolige. Men det galder ikke alle unge og i alle situationer. Det er derfor en rammescetning for rapporten, at de unge har forskellige forventninger og behov til deres forskellige voksne i livet. Rapporten stiller skarpt på hvilke forventninger unge i udskolingen har til deres professionelle voksne, og hvilke emner og problemstillinger de netop knytter til fortroligheden med dem.

Rapportens råd og analyser henvender sig til de professionelle voksne, som udskolingseleverne møder i institutionelle sammenhœenge - og de voksne enkelte elever vil møde i myndighedssammenhœnge. 